\title{
The Income Taxation of Corporate Distributions Under the Internal Revenue Code of 1954
}

\author{
Harold G. Wren*
}

Part I of Subchapter C of the Internal Revenue Code is the result of the efforts of the law-makers, particularly the Senate Finance Committee, to state with complete clarity the law with reference to the taxation of distributions by corporations, including the effects of such distributions on both the distributing corporation and the shareholders. For example, to what extent does a corporation realize gain or loss on a distribution of its assets to its shareholders? What effect does such a distribution have on its earnings and profits? To what extent is gain recognized to the sharcholders at the time of distribution? ${ }^{1}$ If such gain is recognized, does the distribution result in the imposition of an income tax at ordinary income or at capital gains rates? If it is not recognized, what is the effect of the distribution on the shareholder's basis?

Congress has sought to answer these, and a host of other difficult tax questions, by means of Part I of Subchapter C. Moreover, the Commissioner has recently issued a notice of proposed rule making, containing the proposed regnlations for the taxation of corporate distributions. ${ }^{2}$ Yet, despite these attempts at "clarification," several teasing problems remain. The purpose of this article is to explore these situations, and make some suggestions as to what the taxpayer may do to improve his position taxwise under the new Code.

A

\section{DIVIDENDS}

As under the old Code, the new Code defines a dividend as "any distribution of property made by a corporation to its shareholders (1) out of earnings and profits accumulated after February 28, 1913, or (2) out of earnings or profits of the taxable year."3 Section 317(a) defines "property"

* Professor of Law, University of Oklahoma, Norman, Oklahonia.

1 With the possible exception of a stock dividend which does not change the proportionate interests of the stockholders, it would seem that any corporate distribution would involve the realization of income. Hence our inquiry is directed at those situations where despite realization, gain is not recognized.

2 Notice of Proposed Rute MaknNg, Federal Register, Dec. 11, 1954, \$\$ 1.301.1-1.318.4, inclusive (hereinafter cited as Prop. REG.).

3 Int. Rev. Code of 1954, §316(a); INT. Rev. Code of 1939, § 115(a); Prgr. Reo. \$1.316-1(a) (1). Accord, A.I.I., Federat Income Tax Statute \& X 5066 (Feh., 1954 Draft) 
for purposes of corporate distributions as "money, securities, and any other property," excluding stock dividends and stock rights.. The tax effects of a distribution of property on the recipients are outlined in section 301 . Apart from the new fifty dollar exclusion ${ }^{5}$ and four per cent credit, ${ }^{6}$ if the distributee is not a corporation, the law is the same as under the old Code. A dividend paid in money or property is taxable income at ordinary income rates. ${ }^{7}$ A distribution not out of earnings and profits reduces the stockholder's basis for the shares that he holds, ${ }^{8}$ and if in excess of this basis, it is taxed as a capital gain. ${ }^{9}$ To the extent that the distribution is out of increase in value prior to March 1, 1913, it is exempt from tax..$^{10}$

The law has been changed somewhat with reference to distributions where the shareholder is a corporation. A dividend of appreciated property received by a corporate shareholder is income to the extent of the paying corporation's basis ${ }^{11}$ which basis carries over to the payee corporation. ${ }^{12}$ Under the old Code, such a distribution was treated as income to the receiving corporation to the extent of the value of the property, ${ }^{13}$ with the dividends-received credit limited to eighty-five per cent of the paying corporation's basis. ${ }^{14}$ As under the old law, a dividend of depreciated property is income to the recipient corporation to the extent of the fair market value, ${ }^{16}$ and the basis to the shareholder corporation is accordingly stepped down. ${ }^{18}$

Among the various types of distributions which the case law has treated as dividends are the following: withdrawals by, or loans to, principal stockholders, ${ }_{1}^{17}$ payment of premiums on the life of the corporation's principal

hereinafter cited as A.L.I. §......... Several new definitions with reference to what constitutes a "dividend" have been added to the new Code. The so-called "dividend" of an insurance company is expressly excluded from the definition. INr. REv. CODE of 1954, §316(b) (1). A dividend of a personal holding company is defined as a distribution of property "to the extent of [the company's] undistributed personal holding company income . . ." INT. REV. CODE OF $1954, \S 316$ (b) (2).

4 INT. Rev. Code of 1954, §317(a); Prop. Reg. §1.317-1. Stock dividends and stock rights are given special treatment under the new Code. See text at note 94 et seq. infra.

IINT. REv. CODE OF 1954, § 116.

- INT. REv. CODE OP 1954, § 34.

7 INT. Rev. Code of 1954, $\$$ 301(b) (1) (A), (c) (1) ; Prop. Reg. § 1.301-1.

8 INT. REv. CODE OF 1954, § 301 (c) (2).

${ }^{9}$ INT. REv. CODE OF 1954, $\S 301$ (c) (3) (A).

10 INT. REv. CODE OF 1954, \$301(c)(3)(B).

11 INT. Rev. CoDe of 1954, § 301(b) (1) (B) (ii); Prop. Reg. § 1.301-1(d).

12 INT. REv. CoDE OF 1954, § 301(d) (2) (B).

${ }^{13}$ See National Carbon Co., 2 T.C. 57 (1943).

14 INT. REv. Code of 1939, \$ 26(b).

15 INT. REv. CoDE OF 1954, § 301(b) (1) (B) (i).

16 INT. REv. CoDE OF 1954, § 301(d) (2) (A).

17 Regensburg v. Commissioner, 144 F.2d 41 (2d Cir. 1944). 
stockholder, ${ }^{18}$ sales of property to stockholders at less than fair market value, ${ }^{19}$ distributions of stock in another corporation, ${ }^{20}$ distributions of stock rights to purchase stock in another corporation, ${ }^{21}$ distribution of "interest" on bonds ${ }^{22}$ and excessive compensation paid to officers who are also stockholders. ${ }^{23}$

B

EARNINGS AND PROFITS

The Code does not define earnings and profits, except to say that they may be either accumulated or current. ${ }^{24}$ To determine what items are included within the concept, the law sometimes looks to the doctrines of accounting and corporate law. ${ }^{25}$ State and local bond interest, for example, is included even though tax exempt. On the other hand, property acquired by gift is treated as a "contribution to capital," and would be excluded from earnings. ${ }^{28}$ Formal changes with respect to capitalization normally will not involve earnings and profits. A capitalization of earnings, for example, will not remove them from the concept of "earmings and profits" for tax purposes.

The Code and proposed regulations, however, do provide elaborate sets of rules with respect to the effects of certain transactions on earnings and profits. The general rule is that earnings and profits are reduced by the amount of money, the principal annount of any obligations, and the adjusted basis of any other property distributed. ${ }^{27}$

If inventory assets are distributed, any excess of fair market value over adjusted basis increases earnings and profits. Earmings and profits are thereafter decreased by the fair market value of the inventory assets distributed, but the decrease cannot be larger than the earnings and profits

\footnotetext{
18 Paramount-Richards Theatres, Inc., P-H 1944 T.C. Mem. Dec. \f 44274, affd, 153 F.2d 602 (5th Cir. 1946).

10 U. S. Treas. Reg. 118, § 39.22(a)-1(b) ; Prop. Reg. § 1.301-1(j).

${ }^{20}$ Such a distribution may be treated as a property dividend, INT. REv. CODE OF 1954, $\$ 301$, or as a spin-off if a corporate division is involved. INT. REv. CODE of 1954, $\$ 355$.

21 Ramapo, Inc. v. Commissioner, 84 F.2d 986 (2d Cir. 1936); but cf. Palmer v. Commissioner, 302 U.S. 63 (1937).

${ }^{22}$ Fidelity Savings and Loan Association, 23 B.T.A. 1059 (1931), affd, 62 App.D.C. 131, 65 F.2d 477 (1933), cert. denied, 290 U.S. 652 (1934); but cf. I.T. 3095, 1937-2 CoM. Buxx. 217.

23 U. S. TREAS. REG. 118, $839.22(a)-7$.

24 INT. REv. CoDE OF 1954, \$ 312 (a).

25 "Earnings and profits" is a concept peculiar to tax law. Although it does not correspond to taxable income, it does not necessarily follow corporate accounting concepts either. Commissioner v. Wheeler, 324 U.S. 542 (1945).

${ }^{28}$ Cancellation of indebtedness of a corporation may constitute a contribution to its capital. Commissioner v. Auto Strop Safety Razor Co., 74 F.2d 226 (2d Cir. 1934); but cf. INT. REv. CODE OF 1954, \& 61(a) (12).

27 INT. Rev. CODE OF 1954, 8312 (a); Prop. Reo. $81.312-1$.
} 
available for the distribution..$^{28}$ Inventory assets include stock in trade, other assets held primarily for sale to customers in the ordinary course of business, and unrealized receivables or fees. ${ }^{29}$

If a corporation sells or otherwise disposes of property, part of the value of which represents an increment prior to March 1, 1913, earnings and profits are increased or reduced only insofar as gain or loss is recognized with respect to increments in value on or after that date. ${ }^{30}$

If gain or loss is not recognized to a distributee upon a distribution by a corporation, ${ }^{31}$ or if the distributee receives a non-taxable stock dividend or stock right, ${ }^{32}$ there will be no change in earnings and profits. Similarly, the receipt of a stock dividend by a corporation requiring an allocation of basis, or of a distribution which goes to reduce the basis of stock with respect to which such distribution is made, will have no effect on earnings and profits. ${ }^{33}$

That part of a redemption or partial liquidation which is "properly chargeable to capital account" will have no effect on earnings and profits. ${ }^{34}$ In the case of a corporate separation under sections 355 and 356 , the new Code provides for the allocation of earnings and profits under regulations to be issued by the Commissioner, ${ }^{35}$ and the Commissioner has provided that "such allocation shall be made in proportion to the fair market value of the business or businesses retained by the distributing corporation and the business or businesses of the controlled corporation immediately after the rransaction." ${ }^{36}$ Finally, the new Code has inserted a special provision relating to the effect on earnings and profits of a distribution to shareholders

28 INT. Rev. CoDE OF 1954, $\$ 312$ (b) (1) ; Prop. REG. $\$ 1.312 .2$. See also $\$ 311$ (b), providing for the recognition of gain with respect to a distribution of inventory assets by a corporation using the LIFO inventory method. Prop. REG. §1.311-1(b), (c).

29 INT. REv. CODE of 1954, \$312(b) (2) (A). Unrealized receivables and fees are defined as any rights to payment for goods delivered, on account of sales of property other than capital assets, or services rendered, or to be rendered, to the extent that these receivables or fees were not previously includible in income under the method of accounting used by the taxpayer. INT. REV. CODE OF 1954, $\S 312$ (b) (2) (B). In making adjustments to earnings and profits because of distributions of property under $\S 312$ (a) or of inventory assets under $\S 312$ (b), proper adjustment must be made for any liabilities to which the property may be subject. Irr. REv. CODE OF 1954, §312(c); Prop. REg. \$1.312-3.

30 INT. Rev. CODE OF 1954, §312(g); Prop. REg. \$1.312.9.

31 Int. Rev. CODE OF 1954, §312(d) (1) (A); PROP. REg. \$1.312-8.

32 Int. Rev. CODE OF 1954, § 312(d) (1) (B); PROP. REG. \$ 1.312-8. If the distribution was made under the 1939 Code, the question of whether it was non-taxable and whether gain was recognized, for purposes of determining the effect on earnings and profits, is determined under the 1939 Code. IrT. REv. CoDE of 1954, § 312(d) (2).

83 INT. Rev. Code OF 1954, § 312(f) (2); PROP. REg. \$ 1.312-8.

34 INT. REv. CODE OF 1954, \& 312 (e) ; PROP. REG. \$1.312-5.

85 INT. REv. CODE OF 1954, \$312(i).

oo Prop. Reo. \$1.312-10(a). 
while there is outstanding a loan to the distributing corporation from the United States or any agency or instrumentality of the United States. ${ }^{37}$

C

\section{PROPERTY DIVIDENDS}

But despite the copious language of section 312, the Code does not specifically attack the problem of the effect of a distribution of appreciated property on earnings and profits, or how such a distribution should be taxed to an individual shareholder ${ }^{38}$ Under the general rule of section 312 (a), earnings and profits are reduced by the adjusted basis of the property to the corporation at the time of distribution. Would it follow that a shareholder receiving such a distribution would realize income only to the extent of the corporation's adjusted basis? Hardly, since the shareholder would receive a property dividend which is taxable to the extent of the fair market value of the dividend at the time of the distribution. But suppose the corporation has no earnings and profits to cover such fair market value, even though it may have earnings and profits which will cover its adjusted basis for the property. Would the shareholder still realize ordinary income to the extent of the fair market value of the property received?

In order better to understand this problem, let us assume some figures: Mr. $Z$ owns all the stock of $X$ Corporation at a basis of $\$ 1,500 . X$ Corporation holds $Y$ Corporation stock at a basis to $X$ of $\$ 10,000$, but it does not control $Y$. The fair market value of the $Y$ stock is $\$ 30,000$. $X$ Corporation declares a dividend on its $X$ stock payable in $Y$ stock which will distribute all of the $Y$ stock to $Z$, the sole shareholder of $X$.

37 InT. REv. Code of 1954, § 312 (j) ; Prop. Reg. § 1.312-12; cf. George M. Gross, 23 T.C. No. 97 (1955).

38 Cf. A.L.I. $\$ \$ \times 500(\mathrm{e}), \mathrm{X} 500(\mathrm{~m}), \mathrm{X} 507(\mathrm{~b})(8)$ (distributions in kind produce adjustments in earnings and profits for appreciation or depreciation). The taxation of such a distribution to a corporate shareholder is adequately provided for in the Code. If the property has appreciated in value, no gain is recognized to the corporation making the distribution; INT. REv. CODE OF 1954, §311 (a); PROP. REG. § 1.311-(a); the amount of the distribution to the receiving corporation is the adjusted basis of the property to the distributing corporation; INT. REV. CODE OF 1954, §301 (b) (1) (B) (ii); Prop. REG. § 1.301-1(d); earnings and profits are decreased by the adjusted basis of the property; INT. REv. CODE OF 1954, §312(a) (3); Prop. Reg. $\$ 1.312 .1$ (a) (3); and the basis of the property to the receiving corporation is the basis of the property to the paying corporation. INT. REv. CODE OF 1954, $\S 301$ (d)(2)(B); Prop. Reg. \$ 1.301-1(h) (2) (ii).

If the property has depreciated in value, the rules with reference to the non-recognition of gain or loss and the decrease of earnings and profits by the amount of the adjusted basis of the property distributed are the same as in the case of appreciated property; INT. REv. Code of 1954, §311(a); Prop. Rev. §1.311-1(a); INT. Rev. CODE OF 1954, §312(a) (3); Prop. REG. \$1.312-1(a) (3); but the amount of the distribution to the receiving corporation and its basis for the property received is the fair market value of the property at the time of the distribution rather than its adjusted basis in the hands of the distributing corporation. Irr. REv. CODE OF 1954, §301(d)(2)(A); Prop. REg. § 1.301(1)(h) (2) (i). 
Let us further assume four possible situations with respect to the earnings and profits of $X$ Corporation: viz., that $X$ 's earnings and profits are: (1) $\$ 40,000$, i.e., greater than the fair market of the $Y$ stock; (2) $\$ 12,000$, i.e., less than the fair market of the $Y$ stock, but greater than $X$ 's basis; (3) $\$ 8,000$, i.e., less than $X$ 's basis for the $Y$ stock; and (4) zero, i.e., no earnings and profits. In each of these four situations, there are four problems: (1) Does the corporation realize any income on the distribution? (2) How is the shareholder taxed on the distribution? (3) What is the effect of the distribution on $X$ 's earnmgs and profits? and (4) What is the shareholder's basis for the new stock?

It has long been held that a corporation does not realize mcome on the distribution of appreciated property, ${ }^{39}$ and this result has been incorporated into the 1954 Code. Section 311 of the new Code provides that a corporation distributing appreciated or depreciated property realizes no gain or loss, ${ }^{40}$ except: (1) if the distribution is of "lifo" inventory, the excess of the "fifo" value over the "lifo" value is income, ${ }^{41}$ and (2) the excess of any liabihty to which the property is subject over the property's basis is income. ${ }^{42}$ These exceptions, however, do not apply to distributions in complete or partial liquidation. ${ }^{43}$

With reference to the taxation of the shareholder on the distribution, we must consider each of the hypotheticals separately: In situation number (1) it is well established that the shareholder is taxed on the fair market value of what he receives in a property distribution at ordinary mcome rates. ${ }^{44}$ Situation number (2) is the problem in the recent cases, Commissioner v. Hirshon Trust ${ }^{45}$ and Commissioner v. Godley's Estate. ${ }^{46}$ Despite some earlier Tax Court holdings to the contrary, ${ }^{47}$ both the Second and Third Circuits have held that the entire amount of the dividend $(\$ 30,000)$ is taxable to the shareholder at ordinary income rates. This result was reached by the following reasoning: The distribution is a dividend because it is a distribution "out of its earnings and profits." 48 As a dividend, the

39 General Utilities Co. v. Helvering, 296 U.S. 200 (1935); see also cases collected at 1 P-H 1954 Fed. TAX SeRv. \1 10,030; but cf. Colnmissioner v. First State Bank, 168 F.2d 1004 (5th Cir. 1948) (anticipating assignment of income); First Nat. Bank of St. Elmo, Ill. v. United States, 97 F.Supp. 25 (E.D. Ml.1951), aff'd, 194 F.2d 389 (7th Cir. 1952).

40 INT. Rev. CoDe of 1954, § 311(a); Prop. Reg. § 1.311-1(a).

41 INT. Rev. CODE OF 1954, §311(b); Prop. ReG. $\$ 1.311-1$ (b), (c). But note that "the proceeds of the sale of property ... by a shareholder receiving [it] may be imputed to the corporation if, in fact, the corporation made the sale." PROP. REG. $\$ 1.311-1$ (a).

42 INT. Rev. CODE OF 1954, § 311(c); PROP. Reg. § 1.311-1(d).

43 INT. Rev. Code of 1954, § 336; Prop. Reg. § 1.336-1.

44 Binzel v. Commissioner, 75 F.2d 989 (2d Cir. 1935), cert. denied, 296 U.S. 579 (1935).

45213 F.2d 523 (2d Cir. 1954), cert. denied, 348 U.S. 861 (1954).

46213 F.2d 529 (3rd Cir. 1954), cert. denied, 348 U.S. 862 (1954).

47 The cases are collected at 1 P-H 1954 FED. TAX SERv. II 9185-B.

18 INr. Rev. CodE OF 1954, \$316(a); INT. Rev. Code OF 1939, § 115(a), (b). 
fair market value of the property is includible in the gross income of the shareholder, and is taxable at ordinary income rates. ${ }^{40}$ Despite the contentions of some to the contrary, ${ }^{50}$ the new Code does nothing to change the law with respect to this situation. ${ }^{51}$ Perhaps the 84th session of Congress will clarify the treatment of the problem in its amendments to the new Code. ${ }^{52}$

When we come to situation number (3), we have a complicated problem, but it is the writer's belief that the language of the Code provides an answer. Section 301 (c) (1) provides that the "portion of a distribution which is a dividend ... shall be included in gross income," while section 301 (c) (2) and (3) provides that the "portion of the distribution which is not a dividend" shall be taxed on a return of capital theory. While the precise situation in hypothetical number (3) has not been presented in the decided cases, it would seem that a pro ration of that part whicls was a dividend, and that part which was a return of capital, would be demanded by the new Code. Thus, in our hypothetical example, where earnings and profits are $\$ 8,000$, eighty per cent of the distribution $(8,000 / 10,000)$ or $\$ 24,000$ would be treated as a dividend, while the remaining $\$ 6,000$ would be treated as a return of capital. ${ }^{63}$

Situation number (4) is the case Commissioner v. Timken. ${ }^{64}$ Where

49 INT. REv. CoDE OF 1954, $\$ 301$ (b) (1) (A), (c) (1).

50 See, e.g., Mintz and Plumb, Dividends in Kind-The Thunderbolts and the New Look, 10 TAX L. REV. 41, 405 (1954-55).

61 The Commissioner has adopted the rule of Hirshon Trust and Godley. In his proposed regulations concerning the definition of a dividend, he says: "(2) In determining whether a distribution of property, other than money, constitutes a dividend, the fact that the earnings and profits of the distributing corporation are less than the amount of the distribution as determined under section 301 (b) (the fair market value of the property in the case of an individual shareholder), is immaterial.

"(3) The rule of (2) above may be illustrated by the following example: Example. Corporation $A$, with earnings and profits of $\$ 10,000$, distributes property with a basis of $\$ 7,500$ and with a fair market value of $\$ 15,000$ to an individual shareholder in a distribution to which section 301 applies. The amount taxable to the shareholder as a dividend under section $301(\mathrm{c})$ is the entire fair market value of the property distributed." Prop. REc. $\$ 1.316-1$ (a) (2), (3).

Compare the avoidance of the problem in examples in that portion of the proposed regulations concerning the taxation of a property dividend: $\$ 1.301-1$, example (1) (individunl stockholder; basis to corporation and fair market value hypothetically stated to be the same); $\$ 1.301-1$, example (2) (corporate shareholder; amount of dividend to receiving corporation is basis to distributing corporation).

52 At the time of this writing, it has been indicated that the 84th Congress may revamp Subchapter $C$ along the lines of H.R. 8300, P-H LAWYER's WEEKLY REPORX $\$ 2$ (Nov. 22, 1954); ibid. \$2 (Apr. 4, 1955).

$63 Z$ would realize a capital gain of $\$ 4,500(\$ 6,000-\$ 1,500)$. But, query, is the amount realized by $Z$ the basis to $X$ Corporation, $i . e$., $\$ 2,000$ rather than the fair market value of $\$ 6,000$ ? If so, $Z$ would realize a capital gaim of $\$ 500$.

54 141 F.2d 625 (6th Cir. 1944). 
there are no earnings and profits at all, the entire amount of the distribution will be taxed to the shareholder as a return of capital. ${ }^{55}$

Were it not for the Senate Finance Committee's report, the determination of the effects of the four distributions on $X$ Corporation's earnings and profits would not be too difficult. Section 310(a) (3) of the House Bill (H.R. 8300) provided that the earnings and profits of the corporation should be reduced by the "adjusted basis of the property distributed." This would indicate that in each of the four hypothetical situations, $X$ 's earnings and profits would be reduced by $\$ 10,000$, so that after the distribution earnings and profits would be $\$ 30,000, \$ 2,000$, a deficit of $\$ 2,000$, and a deficit of $\$ 10,000$, respectively.

While the Senate did not change the language of the House bill (the section is now section 312(a)(3) of the Code), the Finance Committee commented as follows: ${ }^{58}$

The House report indicated that this rule clarified existing law. Subsequent to the date of the House report two court decisions have taken a position to the contrary. [Citing the Hirshon Trust and Godley cases.] In view of these decisions your committee does not intend any implication from the enactment of section 312 (a) with respect to the effects of a distribution of property on earnings and profits and on the shareholders under the 1939 Code.

The Committee's remarks to the effect that the Hirshon Trust and Godley cases are not in harmony with section 312 seem unwarranted. Both the Second and Third Circuits discussed only the question of the taxability of the property dividend to the individual shareholders, and were in no way concerned with the effect of such distributions on the corporation's earnings and profits. Of necessity, the two questions must be treated separately. ${ }^{57}$ This becomes completely apparent where there is a distribution of depre-

65 The amount realized by $Z$ on the distribution is the fair market value of the $Y$ stock, i.e., $\$ 30,000$. This amount will first go to reduce $Z$ 's basis for the $X$ stock $(\$ 1,500)$ to zero, and the balance $(\$ 28,500)$ will be taxed to $Z$ as capital gain. Michael P. Erburu, 23 T.C. No. 104 (1955); INT. REv. CoDE of 1954 \$301(c) (2), (3). But see Commissioner v. Timken, 141 F.2d 625, 630 (6th Cir. 1944). $Z$ 's basis for the $Y$ stock is the fair market value of the stock $(\$ 30,000)$ as of the time of distribution. INT. REv. CODE OF 1954, §301(d) (1). Butt cf. text following note 58 infra.

56 S. REp. No. 1622, 83d Cong., 2d Sess. 248 (1954) (emphasis added). Query: Did the Committee "intend an implication" with respect to the 1954 Code?

57 See. e.g., Prop. REG. § 1.312-1, example (1): "Corporation $A$ distributes property with a value of $\$ 10,000$ and a basis of $\$ 5,000$. It has $\$ 12,500$ in earnings and profits. The reduction in earnings and profits by reason of such distribution is $\$ 5,000$. Such is the reduction even though the amount of $\$ 10,000$ is mcludible in the income of the shareholder (other than a corporation) as a dividend." But see Staff, Jonnt Congressronal ComantTteE on TAXatron, Sumbrary of the New Provisions of the Internal Revenue Code of 1954, 36 (1955) (size of property dividend received by individual shareholder limited by the amount of earnings and profits in the distributing corporation at the time of distribution). 
ciated property. While the corporation's earnings and profits are reduced by the adjusted basis of the property distributed, the shareholder is not taxed on any amount greater than the fair market value of the property distributed. ${ }^{\text {ss }}$

The question remains as to the basis of the $X$ and $Y$ stock to $Z$ after the distribution. In both situations number (1) and number (2), $Z$ would retain his $\$ 1,500$ basis for the $X$ stock, and would have a basis of $\$ 30,000$ for the $Y$ stock. In situation number (3), $Z$ 's basis for the $X$ stock would be reduced to zero, while his $Y$ stock would have a basis of $\$ 24,000$ plus $\$ 6,000$, or a total of $\$ 30,000$. Similarly, in situation number (4), under section 301 (d) of the new Code, $Z$ 's basis would be zero for the $X$ stock, and $\$ 30,000$ for the $Y$ stock. The difficulty with this position is that it ignores the Timken case which held that, as to the $Y$ stock, $Z$ realized no income to the extent of the difference between $X$ 's basis for the $Y$ stock $(\$ 10,000)$ and its fair market value $(\$ 30,000)$. By this rationale, $Z$ 's basis for the $X$ stock would first be reduced to zero, and the amount of this reduction, plus any excess of the basis of the $Y$ stock to $X$ Corporation over $Z$ 's basis for the $X$ stock, would become $Z$ 's basis for the $Y$ stock, or a total of $\$ 10,000$.

\section{STOCK REDEMPTIONS}

The new Code mcorporates the old rule with reference to a "cancellation or redemption of stock which is essentially equivalent to a taxable dividend." ${ }^{59}$ Originally, this section was inserted imto the law to prevent tax avoidance by means of the typical preferred stock bail-out device. The concept was later expanded to include any redemption which was "essentially equivalent to a taxable dividend," whether or not such redemption followed a distribution of a non-taxable stock dividend. The basic doctrine has been retained in the new Code with somewhat different wording, ${ }^{00}$ and,

\footnotetext{
58 See, e.g., Prop. REg. § 1.312-1, example (2): "The facts are the same as in Example (1) above [quoted in note 57 supra] except that the property has a basis of $\$ 15,000$ and the earnings and profits is $\$ 15,000$. Such is the reduction even though only the amount of $\$ 10,000$ is mcludible in the income of the shareholder (other than a corporation) as a dividend." A similar rule operates where the distributee is a corporation. Supra note 38 .

59 INT. REv. CODE OF 1939, $§ 115(\mathrm{~g})(1)$. Under the new Code, stock is treated as "redeemed ... if the corporation acquires [it] from a shareholder in exchange for property, whether or not the stock so acquired is cancelled, retired or held as treasury stock." INT. REv. CODE OF 1954, §317(b).

${ }^{80}$ The new Code states the general rule that a stock redemption is given capital gains treatment if it meets certain statutory requirements. $\S 302$ (a). The requirements, which are stated disjunctively, include the concept that the distribution is not essentially equivalent to a dividend, $\S 302$ (b) (1), and the three new statutory tests, $\S \S 302$ (b) (2), (3) and (4), discussed in the text. If the redemption fails to meet any one of these requirements, it will be taxed as a dividend. $\S 302$ (d).
} 
in addition, if the redemption falls within any one of three new categories, it will receive capital gains treatment, even though it might not otherwise have qualified. The three new situations are as follows:

(1) Where the redemption is "substantially disproportionate with respect to the shareholder."

(2) Where there is a complete redemption of the shareholder's interest. ${ }^{62}$

(3) Where the stock of a railroad is redeemed in a reorganization under Section 77 of the Bankruptcy Act. ${ }^{63}$

The last of these three is a special category with which we need not be concerned here. ${ }^{64}$

\section{Substantially disproportionate redemptions}

A redemption is "substantially disproportionate" if the percentage of the stockholder's ownership of voting and of the common stock (both voting and non-voting) after redemption is less than eighty per cent of the percentage owned by him before redemption. ${ }^{65}$ The stockholder must also own less than 50 per cent of the total voting power after the redemption. ${ }^{86}$ An example will illustrate the operation of the new rule: ${ }^{67}$

A stockholder owned, before redemption, 60 shares out of a total of 100 shares outstanding, or sixty per cent of the total capital stock. All of the stock is common stock with voting power. To satisfy the "substantially disproportionate" test, it would be necessary for him to redeem at least twentyfour shares. This would decrease his holdings to thirty-six shares, and at the same time, the outstanding stock of the corporation would be decreased to seventy-six shares. After redemption, he would hold 47.4 per cent of the outstanding shares. Since this is less than forty-eight per cent $(80 \%$ of $60 \%$ ), the percentage requirements are satisfied. Moreover, he now owns less than fifty per cent of the total voting power in the corporation, and the voting power requirement is likewise satisfied.

61 INT. REv. CODE OF 1954, § 302 (b) (2) (A); Prop. REg. \$ 1.302-3.

62 INT. REV. CODE of 1954, \$302(b) (3); Prop. Reg. \$ 1.302-4.

${ }^{63}$ INT. REV. CODE of 1954, $\$ 302$ (b) (4). Failure to bring oneself within any one of these three situations will not prevent a stock redemption which is not essentially equivalent to a dividend froin receiving capital gains treatment. INT. REv. CODE OF 1954, \$302 (b) (5).

64 The proposed regulations make no attempt to consider this category.

65 INT. REv. CODE OF 1954, $\$ 302$ (b) (2) (C).

${ }_{68}$ INT. Rev. Code of 1954, \$ 302 (b) (2) (B); Prop. Reg. \$ 1.302-3 (a) (1).

67 PROP. REG. $\$ 1.302-3$ gives the following example of a substantially proportionate redemption: "Corporation $M$ has outstanding 400 shares of common stock of which $A, B, C$ and $D$ (all unrelated) each own 100 shares or 25 per cent. Corporation $M$ redeems 55 shares from $A, 25$ shares from $B$, and 20 shares from $C$. For the redemption to be disproportionate as to any shareholder, such sharcholder must own after the redemptions less than 20 per cent (80 per cent of 25 per cent) of the 300 shares of stock then outstanding. After the redemptions, $A$ owns 45 shares ( 15 per cent), $B$ owns 75 shares ( 25 per cent) and $C$ owns 80 shares (26\% per cent). The distribution is disproportionate only with respect to $A . "$ 
A redemption made pursuant to a plan for a series of redemptions will not qualify as a "substantially disproportionate redemption, unless the entire series likewise qualifies." ${ }^{68}$ The Committee Reports illustrate this rule by the following example:

A corporation has 100 shares of stock (all common, voting stock) outstanding. 55 shares are owned by $A$, and 45 shares are owned by $B$. Pursuant to a plan for a series redemption, the corporation redeems 12 shares of $A$ 's stock. Such a redemption would qualify, if it stood alone. Subsequently, $B$, pursuant to the same plan, redeems 10 shares of stock. Similarly, this distribution would qualify if it stood alone. But, "when the two transactions are reviewed together it is apparent that shareholders $A$ and $B$ have not sufficiently changed their respective proportionate interests in the corporation. Accordingly, ... both redemptions would fail to qualify as substantially disproportionate."

\section{Redemption of a shareholder's entire interest}

Before considering the new capital gains treatment for a redemption of a shareholder's entire interest, we must first examine the attribution rules under the new Code. ${ }^{70}$

Section 302 (c) (1) makes these rules applicable to all stock redemptions. If strictly applied, however, it would often be impossible for a stockholder to be sure of capital gains treatment on a redemption of his entire interest, since any stock owned by a member of his immediate family would be treated as his, and it might not be feasible for such stock to be redeemed. Accordingly, section 302(c) (2) provides an exception to the attribution rules so as to preclude the "family-member rule" from operating with respect to redemptions of a shareholder's entire interest, under certain specified limitations. Before considering these limitations, let us examine the attribution rules in more detail.

The most important of the rules is the family-member rule, which provides that an individual shall be conisdered as owning the stock owned, directly or indirectly, by or for his spouse (if not legally separated) his children, his grandchildren and his parents. ${ }^{71} \mathrm{~A}$ legally adopted child is

68 INT. ReV. CODE OF 1954, \$ 302(b) (2) (D) ; PROP. REG. \$ 1.302-3 (a).

69 S. REP. No. 1622, 83rd Cong., 2d Sess. 234-235 (1954). The figures used in the example given in the report are in error as a result of the Committee's calculation of the percentage required after redemption without regard for the decrease in total outstanding stock as a result of the redemption. INr. REV. CODE OF 1954, $\$ 302(\mathrm{~b})(2)$ (C) (ii) provides that one of the figures in the percentage calculation shall be "the ratio which the voting stock of the corporation owned by the shareholder immediately before the redemption bears to all the voting stock of the corporatiou at such time." (Emphasis added).

70 The new Code provides an elaborate set of rules for determining stock ownership under Subchapter C. INr. REv. CODE of 1954, § 318. Accord, generally, A.L.I. \& X 533.

71 INT. Rev. CODE OF 1954, \$318(a) (1) (A). Prop. Reo. \$1.318-2(a). 
treated as a child of the blood for this purpose. ${ }^{72}$ Similar rules of constructive ownership apply as between partnerships and their partners ${ }^{73}$ estates and their beneficiaries, ${ }^{74}$ trusts and their "substantial owners," ${ }^{\text {"78 }}$ and corporations and their stockholders who own fifty per cent or more in value of the stock. ${ }^{76}$ Stock options, and options to acquire stock options are treated the same as stock for purposes of determining constructive ownership. ${ }^{77}$ If stock may be considered as owned by an individual under either the family-member rule, or the option rule, it shall be treated as owned under the family-member rule. ${ }^{78}$ While stock which is found to be constructively owned under the new Code is treated as actually owned, ${ }^{79}$ such constructive ownership by an individual under the family-member rule is not to be treated as owned by him for the purpose of again applying the constructive ownership rule to make another the owner of such stock..$^{80}$

In order for the attribution rules to have any application to a particular section of Subchapter C, it is necessary that it be stated in the section that the rules apply. Accordingly, the rules are applied in five places in the new Code. One of these relates to certain limitations on net operating loss carryovers. The other four involve corporate distributions or liquidations. They are as follows: (1) section 302, relating to stock redemptions; (2) section 304, relating to redemptions by related corporations; (3) section 306 (b) (1) (A), relating to the disposition of section 306 stock; and (4) section 334 (b) (3) (C), relating to the basis of property received in certain subsidiary hquidations.

Turning now to the limitation on the applicability of the rules to stock redemptions, section 302 (c)(2)(A) ${ }^{81}$ provides that the family-member rule shall not apply to any redemption of an entire stock interest if:

(1) immediately after the distribution, the distributee has no interest in the corporation (including an interest as officer, director, or employee), other than an interest as a creditor, ${ }^{82}$

72 INT. REv. CODE OF 1954, § 318(a) (1) (B).

${ }^{73}$ INT. Rev. CODE OF 1954, § 318(a) (2) (A). Prop. Reg. § 1.318-2 (b), example (1).

${ }^{4}$ INT. Rev. Code of 1954, \$318(a) (2) (A). Prop. Reg. \$ 1.318-2(b), example (2).

75 Int. Rev. Code of 1954, \& 318(a) (2) (B). Prop. Reg. \$ 1.318-2 (b), example (5). Contingent beneficial interests of not more than $5 \%$ are not taken into account for purposes of determining the applicability of the attribution rules. INT. REv. CoDE of 1954, §318(a) (2) (B); PRop. Rec. \$ 1.318-2(b), example (3). "Substantial owners" are those who retain economic control over trusts which they create under the Clifford and related doctrines. INT. REv. CODE of 1954, §§ 671-678.

78 Int. Rev. Code of 1954, § 318(a) (2) (C). Prop. Reg. § 1.318-2 (b), [example (4)].

77 INT. Rev. Code of 1954, § 318(a) (3). Prop. Reg. \& 1.318-2 (c).

78 INT. Rev. CODE OF 1954, § 318(a) (4) (C).

79 INT. Rev. Code of 1954, \& 318(a) (4)(A). Prop. REg. \$ 1.318-3.

80 INT. Rev. Code of 1954, \$318(a) (4) (B). Prop. Reg. \$ 1.318-4.

81 See also Prop. REg. \$ 1.302-4(f).

82 INT. REv. CODE OF 1954, $\$ 302$ (c) (2) (A) (i). For the definition of a creditor for purposes of this section, see PROP. REG. $\$ 1.302-4$ (d). 
(2) the distributee acquires no interest in the corporation (including an interest as officer, director, or employee) within 10 years from the date of the distribution, except by bequest or inheritance, ${ }^{83}$ and

(3) the distributee files an agreement with the Commissioner to notify the government of any such acquisition. ${ }^{81}$ The Commissioner has one year from the date of notification of any such acquisition to reassess the taxpayer's tax liability for the year in which he received the distribution. ${ }^{85}$

The family-nnember rule will be applied, however, if the distributee acquired, directly or indirectly, any of the stock to be redeemed from any one of the "related" persons listed in section 318, within ten years prior to the distribution. ${ }^{86}$ Similarly, if any such person acquired stock which was to be redeemed, from the distributee during the ten-year period prior to distribution, then the rule will be applied. ${ }^{87}$ In both of these cases, however, it must be shown that the avoidance of federal income tax was one of the principal purposes of the acquisition, or disposition, of the stock by the distributee..$^{88}$

It is obvious that the most important part of section 302 relating to stock redemptions is the provision that one can obtain capital gains treatment if he redeems his entire stock interest. While it is true that some limitations have been placed on this section with reference to family corporations (that is, where other members of the distributee's immediate family own stock in a close corporation), it is not at all clear whether these limitations will ever be of any importance.

First, it is necessary to prove tax avoidance in order to make those sections referring to prior acquisitions or dispositions applicable, and even if this is demonstrated the only effect is to make the family-member rule applicable.

Second, capital gains treatment may still be obtained by showing that the redemption was "not essentially equivalent to a taxable dividend," or that it was "substantially disproportionate." The Committee reports are of little help in the determination of what constitutes a distribution which is "not essentially equivalent to a dividend." The Commissioner's proposed regulations indicate, however, that a pro rata redemption which does not

83 INT. REv. CODE OF 1954, §302(c) (2) (A) (ii). This rule applies to acquisitions of stock interests both in the parent corporation and in any subsidiary of such parent. Prop. Reo. $\S 1.302-4(c)$.

84 INT. REv. CODE OF 1954, $\$ 302$ (c) (2) (A) (iii). Notice must be given within 30 days after such acquisition. Prop. REg. $\$ 1.302-4$ (a). The acquisition of assets in the enforcement of the riglits of a creditor does not constitute tbe acquisition of stock. Prop. REG. $\$ 1.302-4$ (e).

85 INT. REv. CODE OF 1954, $\$ 302$ (c) (2) (A). The distributee is required to retain records indicating the amount of tax payable if the distribution liad been treated as a dividend.

86 INT. REv. CODE of 1954, \$302(c) (2) (B) (i).

87 INT. REV. CODE OF 1954, § 302 (c) (2) (B) (ii).

88 INT. REV. CODE OF 1954, § 302 (c) (2) (B). 
involve a "genuine corporate contraction" will "ordinarily be treated" as a dividend, and that "in all other cases ... the question whether a distribution is essentially equivalent to a dividend depends upon the circumstances of each case." ${ }^{89}$ If the first of these can be shown, the fact that the attribution rules are applicable will usually be immaterial; on the other hand, it might be necessary to redeem more stock than just the shareholder's to satisfy the substantially disproportionate test. If the redemption satisfies either one of these, it makes no difference whether the distributee subsequently reacquires the stock or not. .0

Third, a redemption may still qualify for capital gains treatment as a complete or partial liquidation. Here again, it is immaterial whether the taxpayer subsequently acquires the stock previously redeemed or not.

\section{Summary}

It is not possible to guess what the courts will do with section 302 of the new Code, but it cannot be doubted that the questions of statutory interpretation which they must face are extremely difficult. Much of this difficulty can be traced to the redrafting that was done in the Finance Committee. The approach of the House bill was to itemize certain kinds of redemptions that would be given capital gains treatment,' viz: (1) partial or complete liquidations, (2) substantially disproportionate redemptions and (3) redemptions terminating a shareholder's interest. This approach was rejected by the Finance Committee, which intended to "revert to existing law by making the determination of whether a redemption is taxable as a sale at capital gains rates or as a dividend at ordinary income rates dependent, except where it is specifically provided otherwise, upon a factual imquiry." 11 Distributions in complete or partial liquidation were said to be "not within the scope of section 302." 92

The effect of the Senate Finance Committee's treatment of section 302 was to create three categories in lieu of the two categories of earlier law. Under the 1939 Code, a redemption of stock was either a partial hquida-

89 Prop. REG. \$ 1.302-2(b).

90 "If a redemption meets the requirements of paragraph (3) [relating to termination of shareholder's interest] and also the requirements of paragraph (1), [a redemption not essentially equivalent to a dividend], (2) [a substantially disproportionate redemption], or (4) [a redemption of stock issued in a section 77 bankruptcy reorganization] then so much of subsection (c) (2), as would (but for this sentence) apply in respect of the acquisition of an interest in the corporation within the 10-year period beginning on the date of the distribution shall not apply." INT. REv. CODE OF 1954, § 302 (b) (5).

91 S. REP. No. 1622, 83rd Cong., 2d Sess. 233 (1954).

92 Recently, there has been some indication that the 84th Congress will amend Subchapter $C$ along the lines of H.R. 8300, as it was enacted by the House. See P-H LAwYER's WEEkrY REPORT 2 (Nov. 22, 1954). The House bill followed the A.L.I. draft. Cf. A.I.I. § X 530; H.R. 8300 , § 302 . 
tion, or it was a redemption which was essentially equivalent to a taxable dividend. The new Code recognizes that a taxpayer may have a complete or partial liquidation, and makes separate provisions for redemptions. Redemptions are broken down into two categories: (1) those which are entitled to capital gains treatment ${ }^{93}$ and (2) those which are to be taxed as ordinary dividends.

\section{E \\ IIQUIDATIONS}

Confusion is further compounded by the complicated definition of a partial liquidation in section 346. A partial liquidation is defined for purposes of Subcliapter $C$ as either (1) a distribution which is one of a series in a complete liquidation, ${ }^{94}$ or (2) a distribution which is "not essentially equivalent to a dividend, is in redemption of a part of the stock of the corporation pursuant to a plan, and occurs within the taxable year in which the plan is adopted or within the succeeding taxable year." ${ }^{.55}$ Thus, except for the fact that the redemption of the stock must be "pursuant to a plan," and must occur "within the taxable year ... or succeeding taxable year," the definition of a partial liquidation is exactly the same as a redemption under section 302 (b) (1). This is true, even though the statute specifically provides that the fact that a distribution qualifies under section 302 (a) and (b) as a stock redemption which is to receive capital gains treatment is immaterial for purposes of determining whether-a particular distribution is a "partial hquidation."

While the Code itself thus provides little help with reference to what constitutes a "partial liquidation," the report of the Finance Committee makes it clear that the statutory language refers to a "genuine corporate contraction." The case of Joseph Imler ${ }^{97}$ is cited as an example of such a

93 See H.R. 8300, 83d Cong., 2d Sess. §302(a) (2) (1954). As we have seen, these redemptions are further broken down into: (a) redemptions not essentially equivalent to a dividend; (b) substantially disproportionate redemptions; (c) redemptions which terminate a shareholder's entire interest; and (d) redemptions of § 77 reorganization stock.

94 INT. REv. CODE OF 1954, § 346(a) (1).

95 INT. REV. CODE OF 1954, § 346 (a) (2). The statute provides one example (it is specifically stated that the rule should not be limited to it) of a distribution which qualifies under this definition. If before the distribution, there are two or more busmesses which have been actively conducted for at least five years prior to the distribution by the same corporation or by its predecessor from whom the business was acquired in a non-taxable transaction, and after the distribution the hquidating corporation is still actively engaged in at least one business, then such a distribution will be withm the definition of $\S 346(a)(2)$. Whether the distribution is pro rata or not is immaterial for purposes of meeting these requirements. INT. REv. CODE OF 1954, § 346(b). PrOP. REG. § 1.346-1(b), (c).

96 S. REP. No. 1622, 83rd Cong., 2d Sess. 262 (1954). The Commissioner's proposed regulations also indicate that a "genuine contraction of the corporate business" will constitute a partial liquidation. Prop. REg. § 1.346-1(a).

8711 T.C. 836 (1948), acq., 1949-1 Cor. Buxs. 2. A recent case illustrating a partial 
genuine contraction. The distribution of a reserve for expansion is cited as an example of a type of distribution which would not qualify as a "partial liquidation." 98 The report also makes it clear that once a distribution qualifies as a partial liquidation, the attribution rules will not apply. To quote the Committee:

For example, if a shareholder terminates his interest in a corporation pursuant to a partial hquidation in which he and his son each owned half the stock, there would be no sanction under section 302 (c) (2) (A) in the event of his reacquiring an interest in the corporation within ten years from the date of the distribution.

To illustrate the type of problem likely to arise when the courts are faced with rationalizing sections 302 and 346 , let us consider the case of Commissioner v. Roberts, ${ }^{100}$ to see if it can be determined what result would be reached under the new Code. In that case, the taxpayer and his brother owned the entire outstanding stock (2,000 shares) of a corporation doing a wholesale heating and plumbing business. The taxpayer owned 1,500 shares while his brother owned 500 shares. In 1943, the brother died, and, by his will, left all his stock to the taxpayer. In 1944, the corporation redeemed the 500 shares for $\$ 92,000$, the value of the stock for estate tax purposes. The Tax Court found that the $\$ 92,000$ payment by the corporation was a distribution in redemption of all of that portion of the corporation's stock bequeathed by the taxpayer's brother and, under the Commissioner's regulations, constituted a partial liquidation. Since the taxpayer had a basis of $\$ 92,000$ for the 500 shares, he realized no gain on the distribution.

On appeal by the Commissioner, however, the Fourth Circuit took the view that the taxpayer was the sole stockholder both before and after the redemption, and the distribution was therefore pro rata, and "essentially equivalent to the distribution of a taxable dividend" under section $115(\mathrm{~g})$ of the old Code.

Had the stock been held by the executor at the time of the redemption as the brother's property, a different result might have been reached.

Let us assume a hypothetical situation mvolving the same facts, except (1) instead of two brothers, we are concerned with a father and son, and (2) the father dies intestate, leaving his son as his sole heir. The corporation redeems the 500 shares of the father from his executor at $\$ 92,000$ the value of the stock for estate tax purposes. Under the new Code, such a

hquidation where there was a pro rata distribution is Commissioner v. Sullivan, 210 F.2d 607 (5th Cir. 1954).

98 S. REP. No. 1622, 83rd Cong., 2d Sess. 262 (1954) ; Prop. Reg. § 1.346-1(a).

00 S. REP. No. 1622, 83rd Cong., 2d Sess. 262 (1954). The proposed regulations also make this point clear. Prop. REg. \$1.302-1.

100203 F.2d 304 (4th Cir. 1953). 
redemption would not qualify as a "partial liquidation," since there is no "genume corporate contraction." 101 It could not qualify as a "substantially disproportionate" redemption, since under the attribution rules, all of the son's stock would be deemed to be the father's.

On the other hand, since the requirements of section 302 (c) (2)(A) can be satisfied, the family-nnember rule will not be applied, and the redemption would qualify as a "complete redemption of all of the stock of the corporation owned by the shareholder." If, however, the son acquired any portion of his stock from his father during the ten years prior to the redemption, and one of the principal purposes of such acquisition was the avoidance of federal income tax, then, under section 302 (c)(2)(B), the family-inember rule becomes applicable, and it will not be possible to have a redemption of the father's entire interest. While an acquisition by bequest or inheritance is exempt from these rules, it will apparently be unwise to make any transfers within ten years prior to the death of the father. Thus, the new Code would seem to restrict estate planning with respect to the typical family corporation. Of course, it might still be contended that the transfer was a redemption which was "not essentially equivalent to a dividend" under section 302 (b) (1) and was entitled to capital gains treatment for this reason. ${ }^{102}$

Still another possibility for getting out earnings and profits as capital gains remains under the new Code. Assume a corporation has extensive cash resources. Such a corporation could carry out a complete liquidation, distributing all the assets to its shareholders. The shareholders would then retain the cash, and transfer the busmess assets to a new corporation which would continue the operation of the business. Section 357 of the House bill sought to tax such a complete liquidation, followed by subsequent reincorporation in much the same way as a redemption essentially equivalent to a dividend, unless the taxpayer could establish that "such transactions did not lave as one of their principal purposes the avoidance of tax on corporate distributions of property." 103

This section was omitted from the Finance Committee's version of Subchapter C. The report of the Conference Committee, however, makes it clear that this particular device cannot be used to get earnings out at capital gains rates. Said the Committee: ${ }^{104}$

This provision gave rise to certain technical problems and it has not been retained in the bill as recommended by the accompanying conference re-

101 This is true even though it would have qualified under the old Code.

102 Throughout this example, we have assumed that the stock redeemed would be treated as the father's. If, on the other hand, it be treated as the son's, the rule of the Roberts case would be apphicable.

103 H.R. 8300, 83rd Cong., 2d Sess. $\$ 357$ (b) (1954).

104 Conr. Rep. No. 2543, 83rd Cong., 2d Sess. p. 41 (1954)! See also, A.I.I. $\$$ X 522. 
port. It is the belief of the managers on the part of the House that, at the present time, the possibility of tax avoidance in this area is not sufficiently serious to require a special statutory provision. It is believed that this possibility can appropriately be disposed of by judicial decision or by regulation within the framework of the other provisions of the bill.

Despite the Conference Committee's optimism with respect to the eventual disposition of the problem of liquidation and subsequent reincorporation, the fact remains that the new Code does not prohibit this device for getting earnings out at capital gains rates. The Finance Committee also eliminated the defimition of "complete liquidation" which appeared in the House bill ${ }^{105}$ but provided without qualification that "amounts distributed in complete liquidation of a corporation shall be treated as in full payment in exchange for the stock"106 - in other words, such distributions sliall receive capital gains treatment. Moreover, the Finance Committee added another section providing that section 301, relating to the method of taxing dividends to sliareliolders, slould not apply to "any distribution in partial or complete liquidation." 107 In the face of this language, the "plain meaning" rule of statutory construction will have to be ignored by the Commissioner and the courts to accomplish the result expected by the Conference Committee. In the Commissioner's proposed regulations it is provided: ${ }^{108}$

A liquidation which is followed by a remcorporation or which is preceded by an incorporation of part of the assets of the liquidating corporation may ... have the effect of the distribution of a dividend or of [boot].

$\mathbf{F}$

STOCK DIVIDENDS

\section{Taxation of the Distribution}

Stock dividends liave liad an extremely tortuous history in the development of tax law. The original income tax statute made no mention of stock dividends as such, and the Supreme Court lield that they were not taxable under the statutory concept of "income." ${ }^{109}$ Subsequently, in the Revenue Act of 1916, Congress sought to tax them as a dividend to the extent of their fair market value at the time of distribution, but the Court ruled that a stock dividend was not within the concept of "income" for constitutional purposes. ${ }^{110}$ Thereafter, Congress provided that stock dividends slould not

105 H.R. 8300, 83rd Cong., 2d Sess. § 336(b) (1954).

108 Int. Rev. CODE of 1954, § 331(a) (1).

107 INT. REv. CODE OF 1954, § 331(b).

108 Prop. REg. \$ 1.331-1 (b).

109 Towne v. Eisner, 245 U.S. 418 (1918).

110 Eisner v. Macomber, 252 U.S. 189 (1920). 
be "subject to tax,"111 and that the basis of the original stock held by the stockholder should be allocated over both the old and the new stock. In 1936, however, the Supreme Court held that where a stockholder receives a stock dividend which gives him an interest proportionately different from what his former stockholdings represented, he realizes income. ${ }^{112}$ Accordingly, he would be entitled to a stepped-up basis. Subsequently, Congress incorporated this "proportionate interest" test into the old Code, by providing that a stock dividend should not be income "to the extent that it does not constitute income ... within the meaning of the Sixteenth Amendinent." 113

The difficulties of the proportionate interest test are well illustrated by the cases Wiegand v. Commissioner ${ }^{114}$ and Tourtelot v. Commissioner, ${ }^{115}$ both of which involved the same distribution. A corporation had two classes of stock outstanding, class A and class B. Class A had preferences as to dividends and as to liquidation; then the class $B$ was entitled to a stated amount of dividends, and rights on hquidation; after which the two classes would share equally. A stock dividend was declared of one new share of A stock for every two shares of A, and one new share of B stock for every two shares of B. Both the Third and Seventh Circuits treated this distribution as a non-taxable stock dividend, despite the fact that after the dividend, class A shareholders had a larger preference both as to dividends and as to assets on liquidation.

The new Code eliminates the proportionate interest test and makes all stock dividends non-taxable, ${ }^{116}$ except in two situations:

(1) where "the distribution is made in discharge of preference dividends for the taxable year of the corporation in which the distribution is made or for the preceding taxable year," and ${ }^{117}$

(2) where the stockholder has the option of taking either cash or property in lieu of the stock dividend. ${ }^{118}$

Section 307 of the new Code provides for the allocation of the basis of the shareholder's old stock to new stock or stock rights received by way of a non-taxable stock dividend. ${ }^{119}$ If the distribution is of stock rights of a

111 Revenue Act of $1921, \S 201$ (d).

112 Koshland v. Helvering, 298 U.S. 441 (1936).

113 INT. REv. CODE of 1939, §115(f). That such was the Congressional intent was held in Helvering v. Griffiths, 318 U.S. 371 (1943).

114194 F.2d 479 (3d Cir. 1952).

115189 F.2d 167 (7th Cir. 1951).

116 INT. Rev. CoDE of 1954, § 305(a). PROP. REg. § 1.305-1. Accord, A.L.I. § X 510, except that shareholder might elect to treat preferred or common as taxable.

117 INT. REv. CODE of 1954, §305(b) (1). Such stock may be treated as "section 306 stock" to the extent that it is not taxable under section 305. Prop. REG. $\$ \S 1.305-1,1.306-3$ (c).

118 INT. Rev. CODE OF 1954, § 305(b) (2). Prop. Reg. § 1.305-2.

119 INT. Rev. CODE OF 1954, § 307 (a). PROp. REg. § 1.307-1. 
fair market value less than fifteen per cent of the value of the old stock, the stockholder may elect to take such rights at a zero basis, and not allocate anything from his old stock. ${ }^{120}$ Such an election must be made by the taxpayer in the return for the year in which the rights were received, and is irrevocable. ${ }^{121} \mathrm{~A}$ distribution of stock dividends or stock rights which is non-taxable has no effect on the earmings and profits of the corporation. ${ }^{122}$

\section{Taxation of the Subsequent Disposition}

Under the 1939 Code, if a corporation had only one class of stock outstanding (for example, common stock), it could declare a dividend on the common in preferred. Since the shareholders would have proportionately the same interests after such a distribution as before, this was a non-taxable stock dividend. The shareholders would then sell their newly acquired preferred to a party interested in making an investment (often an insurance company), realizing a capital gain to the extent of the difference between what they received and their allocated basis for the new stock. To protect the insurance company's investment, the preferred stock would often have a sinking fund provision, under which it would be redeemed by the company over a period of years. After all the preferred had been redeemed, the company would then be in a position to start the whole process over again, since it would now have only one class of stock outstanding. This bail-out device was sustained in the now familiar case Chamberlin v. Commissioner. ${ }^{23}$

Congress sought to reverse the Chamberlin case by adding a new section in the 1954 Code, Section 306. The plan of this section is to first define what constitutes "section 306 stock," and then state the method of taxation of such stock upon its disposition. Section 306 stock is defined as:

(1) any stock, other than common, received by way of a non-taxable stock dividend; ${ }^{124}$

(2) any stock, other than common, which is received in a corporate reorganization or separation, to the extent that the effect of such receipt was substantially the same as the receipt of a non-taxable stock dividend, or the stock was received in exchange for section 306 stock; ${ }^{125}$ or

(3) any other stock, the basis of which is determined by reference to the basis of section 306 stock. $^{128}$

120 Int. Rev. Code of 1954, §307(b) (1). Prop. Reg. § 1.307-2. Accord, generally, A.L.I. $\S \mathrm{X} 511$ (b).

121 INT. Rev. CODE OF 1954, § 307 (b) (2). Prop. Reg. § 1.307-2.

122 INT. Rev. Code of 1954, § 312 (d) (1) (B); Prop. Reg. \$ 1.312-8.

123207 F.2d 462 (6th Cir. 1953), cert. denied, 347 U.S. 918 (1954).

124 INT. Rev. Code of 1954, § 306(c) (1) (A); Prop. Reg. § 1.306-3(c).

125 INT. REv. Code of 1954, § 306(c) (1) (B); Prop. Reg. \$1.306-3(d).

126 Int. Rev. CODE OF 1954, § 306 (c) (1) (C); Prop. Reg. \$ 1.306-3 (e). 
Any stock received by way of a distribution which would not have qualified as a "dividend," because of an absence of earnings and profits, is specifically excluded from the definition of "section 306 stock,"127 and stock acquired through the exercise of rights is treated as stock distributed at the time of the distribution of the rights, to the extent of the fair market value of the rights at the tinue of distribution. ${ }^{128}$ If section 306 stock which is issued with respect to common stock is subsequently exchanged for common stock in the same corporation, then the common stock so received will not be treated as section 306 stock. ${ }^{129}$ On the other hand, common stock with respect to which there is a privilege of converting into stock other than common, is not "common stock" for purposes of the definition, and will therefore be treated as section 306 stock. ${ }^{130}$

Once it has been determined that the stock in question is "section 306 stock," the rule for the taxation of such stock is applied at the time of its disposition. ${ }^{131}$ If the disposition is by way of redemption, the amount realized is taxed as a dividend, ${ }^{132}$ to the extent that there are earnings and profits at the time of the redemption. ${ }^{133}$ If the disposition is by way of a sale, then the amount realized on the sale is treated as gain on the sale of property which is not a capital asset-that is, ordinary income-to the extent that the amount realized would have been a dividend if the corporation had distributed cash instead of a stock dividend. In other words, the shareholder will realize ordinary income up to his share of the corporation's earnings and profits as of the tinue of distribution. ${ }^{184}$ If the amount realized exceeds the amount that would have been a dividend, any

127 Irr. Rev. Code of 1954, § 306(c) (2); Prop. Reg. \$ 1.306-3(a).

128 Ivr. Rev. CoDe of 1954, § 306(d) (2); Prop. REG. \$ 1.306-3(b).

129 INT. Rev. Code of 1954, § 306 (e) (1); Prop. Reg. \$ 1.306-3(f).

130 INr. Rev. CoDe of 1954, § 306(e) (2); Prop. REG. $\$ 1.306-3$ (f).

131 The rule as finally worked out in the Conference Committee is based largely on the Senate Finance Committee's version of section 306. The House Bill deferred the application of the rule to the time of redemption, regardless of whether such redemption was by the original recipient or by his transferee. Cf. IrT. REv. CoDE of $1939, \S 115(\mathrm{~g})(1)$ (1939) (taxation as a dividend as of the time of distribution, rather than disposition). See also, A.L.I. $\$ \$ \times 519, X 531$ (bail-outs prevented by treating sale of preferred stock in effect as a taxable redemption, with certain exceptions).

132 Int. Rev. Code of 1954, § 306(a) (2); Prop. Reg. \$ 1.306-1(c).

133 The Senate Finance Committee's report inakes it elear that it is not intended that the redemption rules under $\S 302$ should be applied to a redemption under $\S 306$ (a) (2): "It should be noted that where section 306 stock is redeemed the rules of section 302 (a) and (b), relating to cases where amounts received in redemption of stock will be taxed at capital gain rates, are not applicable. Section 306 operates independently of section 302 and contains its own rules concerning instances where your committee does not consider it appropriate to tax proceeds received with respect to section 306 stock at the rates applicable to ordinary income." S. REP. No. 1622, 83rd Cong, 2d Sess. 242-243 (1954). The Commissioner's proposed regulations provide: "In the case of a redemption, the amount of earnings and profits of the distributing corporation at the time the section 306 stock was distributed is immaterial." Prop. REG. $\$ 1.306-1$ (c).

134 Int. Rev. Code of 1954, § 306(a) (1) ; Prop. Reg. \$ 1.306-1 (a), (b). 
such excess is capital gain to the extent that it exceeds the shareholder's adjusted basis for his section 306 stock.

An example will illustrate the application of the rule:

On July 1, 1954, $X$ Corporation has the following balance sheet:

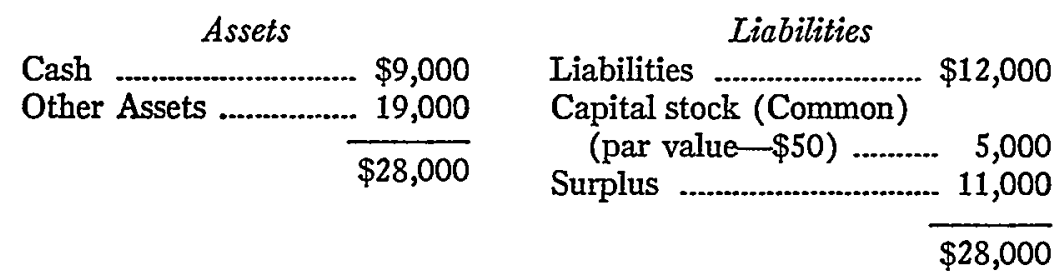

On that date, $X$ Corporation declares a dividend of preferred stock payable at the rate of one share for every share of common stock held. The preferred stock is to have a par value of 100 dollars.

Mr. $Y$ owns 5 shares of $X$ stock which cost him forty-five dollars a share. He receives five shares of the new preferred which have a fair market value equal to twice the value of the common stock. Subsequently; he sells the preferred for 150 dollars a share. How should the subsequent sale be taxed?

Mr. $Y$ realized 750 dollars on the sale. 550 dollars would be ordinary income; fifty dollars ( $\$ 200-\$ 150)$ would be capital gain.

If, in the above example, Mr. $Y$ had redeemed his stock, instead of selling it, he would have been taxed on the entire amount realized as an ordinary dividend to the extent that there were earnings and profits at the time of redemption. If the corporation had no earnings and profits as of this time, he would realize capital gaim to the extent that what he received on the redemption exceeded his allocated basis for the new preferred. Thus, if $X$ Corporation subsequently suffered an operating loss of 11,000 dollars which reduced its earnings and profits to zero, and the new corporation redeemed his new preferred at par, he would realize capital gain in the amount of 350 dollars $(\$ 500-\$ 150)$.

Thus, a corporation first distributes a stock dividend. Since nearly all stock dividends are non-taxable under the new Code, it is not necessary that there be only one class of stock outstanding as in the Chamberlin case. Should the earnings and profits of the corporation increase after such a distribution, the value of the section 306 stock will increase in the hands of the shareholders, making it possible for them to sell at a price above their respective pro rata shares of earnings and profits as of the time of distribution. Any amount which they realize in excess of their pro rata shares will receive capital gains treatment.

If, on the other hand, the earnings and profits of the corporation should decrease subsequent to a distribution of section 306 stock, the corporation 
can redeem the stock, and the shareholders will receive capital gains treatment to the extent that there are no earmings and profits available to cover the redemption. ${ }^{135}$

The best time to declare a stock dividend will be after earnings and profits have first been paid out by way of a cash dividend. ${ }^{130}$ The recipients will then be assured of capital gains treatment upon the subsequent disposition of their stock. This combination of regular cash dividends and occasional stock dividends may prove to be the most satisfactory dividend arrangement under the new Code.

In addition, it may still be possible to get capital gains treatment for the entire amount realized on the disposition of section 306 stock under one of the statutory exceptions to the rule. Section 306(b) provides that the rule shall not be applied in any of the following cases:

(1) where the disposition completely terminates the shareholder's interest; ${ }^{137}$

(2) where the disposition is a redemption in complete or partial liquidation of the corporation; ${ }^{138}$

(3) where no gain or less is recognized on the disposition; ${ }^{130}$ or

(4) where the shareholder establishes that the distribution and subsequent disposition was not "in pursuance of a plan having as one of its principal purposes the avoidance of federal income income tax." 140

In the first exception, the disposition may be either by way of sale or redemption. If a sale, it must be to some person other than one whose stock ownership would be treated the same as the shareholder's under the attribution rules, ${ }^{141}$ and it must terminate the shareholder's entire stock interest. ${ }^{142}$ If a redemption, it is treated like a redemption of a shareholder's

135 See S. Rep. No. 1622, 83rd Cong., 2d Sess. 242 (1954): “... if the section 306 stock was distributed at a time when there wasn't an amount of corporate earnings attributable to it equal to its full fair market value at that time, but if there are no corporate earnings, accumulated or current at the time of redemption, the amount received on redenption of section 306 stock would be treated under section 301 as a return of capital."

${ }^{136}$ The distribution of a stock dividend does not violate dividend law for corporate law purposes, BaLIantane, Corporations 482 (1946). Moreover, unrealized appreciation may be the basis for a stock dividend, even though it would not affect "earnings and profits" for tax purposes. State statutes customarily recognize that shares may be redeemed from either capital or surplus. BALIANTINE, CORPORATIONS 619 (1946).

137 Int. Rev. CoDE of 1954, \$306(b) (1); Prop. Reg. \$1.306-2 (a).

138 Int. Rev. Code of 1954, §306(b) (2) ; Prop. Reg. § 1.306-2(b) (1).

130 INT. REv. CODE OF 1954, § 306(b) (3) ; Prop. Reg. \$ 1.306-2 (b) (2).

140 INT. REv. CODE OF 1954, § 306(b) (4); Prop. REg. \$ 1.306-2(b) (3).

141 INT. REV. CODE OF 1954, § 306(b) (1) (A) (ii); Prop. REG. § 1.306-2(a).

142 INT. REv. Code of 1954, $\$ 306$ (b) (1) (A) (iii). The Conference Counmittee Report makes it clear that the terminating shareholder is not prohibited from retaining an interest as a director or an employee. Conf. REP. No. 2543. 83rd Cong., 2d Sess. 35 (1954). The proposed 
entire interest under section 302 (b) (3), and the attribution rules, as among members of the family, are waived to the same extent as under section $302(\mathrm{c})(2) \cdot .^{143}$

In the case of the second exception, the disposition is by way of redemption only; while in the third and fourth exceptions, it may be by way of redemption or other disposition. The Finance Committee's report makes it clear that the fourth exception "is intended to apply to the case of dividends and isolated dispositions of section 306 stock by minority shareholders who do not in the aggregate have control of the distributing corporation. In such a case it would seem to your committee to be inappropriate to impute to such shareholders an intention to remove corporate earnings at the tax rates applicable only to capital gains." 144

To summarize the operation of section 306:

(1) We first determine whether the stock involved comes within the definition of "section 306 stock."

(2) Then we see if the disposition falls within any of the statutory exceptions to the general rule:

(a) a termination of a shareholder's interest,

(b) a redemption in liquidation,

(c) a non-taxable disposition, or

(d) a transaction not in pursuance of a plan for avoidance of tax.

(3) Finally, if the disposition does not come within any of the exceptions, we apply the general rule for the taxation of the disposition, depending upon whether the disposition is by way of redemption or not. If the disposition is by way of redemption, the amount realized is taxed as ordinary income to the extent of the taxpayer's pro rata share of earnings and profits as of the time of redemption. If the disposition is not by way of redemption, the amount realized is taxed as ordinary income to the extent of such share as of the time of the distribution of the stock dividend. Any excess receives capital gains treatment.

In addition to these basic rules, section 306 also makes special provisions for three problems of lesser importance:

(1) dispositions of section 306 stock by nonresident aliens or foreign corporations; ${ }^{145}$

(2) changes in terms and conditions of stock; and $\mathrm{d}^{146}$

regulations similarly provide: "In the case of a sale, only the stock interest need be terminated." Prop. REG. $\$ 1.306-2$ (a).

143 Prop. ReG. \$ 1.306-2(a).

144 S. Rep. No. 1622, 83rd Cong., 2d Sess. 243-244 (1954). See also Prop. Reg. § 1.306-2

(b) (3).

145 Int. Rev. Code of 1954, § 306(f); Prop. Reg. § 1.306-3(h).

146 INT. Rev. Code of 1954, § 306(g); Prop. Reg. § 1.306-3(g). 
(3) stock received in distributions and reorganizations to which the 1939 Code was applicable. ${ }^{147}$

The first of these problems is of a higlily specialized nature. Where section 306 stock is disposed of by a nonresident alien or foreign corporation, it will be treated as derived from the same source (that is, within or without the United States) as would liave been the source if the money had been received from the corporation as a dividend at the time of the distribution of the stock.

The second of these special provisions is intended to prevent the avoidance of the application of section 306 by means of changing the terms of the stock. If a substantial change is made in the terms or conditions of any stock, then, for section 306 purposes, the fair market value is its fair market value at the time of its distribution or at the time of the change, whichever is higher; ${ }^{148}$ and the stock's ratable share of earnings and profits is determined as of the time of the distribution or the time of the change, whichever results in the higher ratable sliare. ${ }^{140}$ Moreover, the fact that the corporation had no earnings or profits at the time of the distribution will not prevent the stock from being section 306 stock unless the corporation also liad no earnings or profits as of the time of the change..$^{150}$

The last of these three special provisions is designed to make section 306 inapplicable to any stock received under a distribution or reorganization under the 1939 Code. If such stock is disposed of after June 22, 1954, the provisions of the 1939 Code, as modified by the sections of the 1954 Code which are applicable, other than section 306 , will be applied in determining whether or not the disposition or redemption resulted in a dividend.

\section{CONCLUSTON}

Part I of Subchapter $\mathrm{C}$ has undoubtedly brought about some clarity in the law with reference to income taxation of corporate distributions. The fact remains, however, that there are a number of problems still unanswered in the new Code. I have sought to examine a few of these:

(1) The taxability of a distribution of property. Where the corporation las earnings and profits to cover the property's basis, but not its fair market value, such a distribution is taxable as ordinary income to the recipient shareholder to the extent of the fair market value of the property distributed. In short, the Hirshon and Godley cases are just as good law under the new Code as under the old, despite some indications in the Committee re-

147 INT. Rev. CoDe of 1954, § 306(h); Prop. Reg. § 1.306-3(i).

148 Int. Rev. Code of 1954, § 306 (g) (1) ; Prop. Reg. $\$ 1.306-3$ (g) (1).

149 Ivt. Rev. CODE of 1954, $\$ 306$ (g) (2) ; Prop. Reg. $\$ 1.306-3(\mathrm{~g})(2)$.

150 Irt. Rev. Code of 1954, §306 (g) (3); Prop. Reg. § 1.306-3 (g) (3). 
ports to the contrary. The Commissioner in his proposed regulations adheres to this view.

(2) The taxability of a stock redemption. Under the old Code, a stock redemption was taxed either as being essentially equivalent to a taxable dividend, or as a redemption in partial liquidation, in which case, it received capital gains treatment. In its attempt to aid the taxpayer, the Code creates a new area which will be hard to isolate. It first sets out certain types of redemptions which will be given capital gains treatment, if certain statutory standards are satisfied. It then creates a new statutory concept: a redeinption which is "not essentially equivalent to a dividend." Presumably, any redemption which can qualify neither as a partial liquidation because it is not a "genuine corporate contraction," nor as a redemption entitled to capital gains treatment under one of the new special redemption sections, may still get capital gains treatment if it can prove that it is "not essentially equivalent to a dividend." But neither the Committee reports nor the Commissioner's proposed regulations give any hint as to what might come within the category, other than those distributions which would be entitled to capital gains treatment for other reasons.

(3) The taxability of a complete liquidation and subsequent reincorporation. Instead of making specific provision for the solution of this problem, the Conference Committee felt that it could be "appropriately disposed of by judicial decision or by regulation." Yet, the plain language of the Code would seem to demand capital gains treatment for any complete liquidation: (1) It is first provided that any distribution in complete or partial liquidation shall be given capital gains treatment; (2) it is next provided that the rules with respect to the taxation of dividends as ordinary mcome shall not be applied to distributions in coinplete or partial liquidation; and (3) a partial liquidation is defined as a distribution which is "not essentially equivalent to a dividend." In the absence of a similar definition for a "complete liquidation," it would seem reasonable to argue that it was the intent of Congress as seen from the plain uneaming of the statute, to give complete liquidations capital gains treatment in all cases. The chances of success for such an argument are remote, however, in view of the language of the report of the Conference Committee and the Commissioner's proposed regulations. Both of these indicate that a complete liquidation followed by subsequent remcorporation will be treated as a dividend distribution, despite the absence of any special provisions in the Code. Another possibility, however, would be to say that a complete liquidation was the same as several redemptions of the various shareholders' entire interests, and therefore the transaction should be given capital gains treatment under section 302 (b) (3). While the subsequent reincorporation would be deened 
a reacquisition of stock previously redeemed, thereby causing the stockholders to lose the benefit of the waiver of the family-member attribution rule, there is nothing in the statute to indicate that this would deny them capital gains treatment.

(4) The taxability of dispositions of section 306 stock. The new Code has created a loophole in the case of section 306 stock for which there is no apparent justification. The effect of the new law is to permit partial capital gains treatment of dividend distributions by way of stock dividends. If a corporation's earnings and profits increase after the distribution of a non-taxable stock dividend, a corresponding increase in the fair market value of the section 306 stock will be given capital gains treatment; if earnings and profits decrease after the distribution of such a stock dividend, capital gains treatment could be obtained by way of a redemption, to the extent of the decrease. Both the Committee reports and the Commissioner's proposed regulations indicate that this was intended, but the obvious tax avoidance possibilities inherent in the new rule may well cause the 84th Congress to reexamine the wisdom of section 306. 